KONSTRUKTIVISME, Vol. 8, No. 1, Januari 2016

p-ISSN: 1979-9438, e-ISSN: 2445-2355

FKIP Universitas Islam Balitar, Blitar

Web: konstruktivisme.unisbablitar.ejournal.web.id

\title{
G*GOLD APPROACH TO CHARACTER EDUCATION: A REFLECTIVE STUDY
}

\author{
Supriyono \\ Universitas Islam Balitar \\ JI.Mojopahir 2-4 Blitar \\ Email: yonsupriyono@gmail.com
}

\begin{abstract}
This paper presents a reflective study on people character development efforts using G*GOLD (Greatness, Gratitude, Obedience, Love, and Discipline) Approach. This study focuses on the reflection of how $G^{*}$ GOLD Approach has contributed to the people character development and this aims at describing the potential impact to contribute to people character development. It has been found out that this approach potentially makes contribution to people character development. Therefore, it is suggested that a further scientific research on the $G^{*} G O L D$ Approach in developing people character for the benefit of the Nation character building is conducted.
\end{abstract}

Key-words: Character education, $\mathrm{G}^{*}$ GOLD Approach

\begin{abstract}
Abstrak
Makalah ini menyajikan studi reflektif mengenai pengembangan karakter manusia menggunakan pendekatan $G^{*}$ GOLD (Kebesaran, Rasa Syukur, Kepatuhan, Cinta dan Disiplin). Kajian difokuskan pada bagaimana $\mathrm{G}^{*} \mathrm{GOLD}$ memberi kontribusi pada pengembangan karakter seseorang dan bagaimana potensi pengaruhnya dalam karakter seseorang. Hasil kajian menunjukkan bahwa ${ }^{*} G O L D$ memiliki kontribusi dalam pembentukan pengembangan karakter. Karena itu, disarankan agar dilakukan penelitian ilmiah menggunakan pendekatan $\mathrm{G}^{\star} \mathrm{GOLD}$ untuk pengembangan karakter manusia dan pengembangan kepribadian bangsa.
\end{abstract}

Kata-Kunci: pendidikan karakter, pendekatan $G^{*}$ GOLD

Nation character building has been important and voiced since the independence of Indonesia Republic. Our primary aim in the nation character building has been to establish the independent dignified civilized prosper nation to achieve the proclaimation ideals for Indonesia Republic, the Pancasila and United and Diversity Country, State, and Nation. Our challenges have been what Soekarno (1957:30) called laziness, egosentrism, greediness, consumerism, pornographic, wild behavior, and corruption. With the advancement of information technology, the practice of participative democracy and decentralization, globalization and 
glocalization, and open market, we even have more challenges in people characters. Furthermore, Supriyono (2012:161) says that the obvious challenges include non-good governance practices in various public services, various cases including corruption, stealing, robbing, human trafficking, yougnster delequency, community fights, unconstructive demonstration, terorrism, and other kinds of crimes. These will be the continuing problems of our nation that hinder the efforts to establish independent and dignified nation.

To overcome such problems, Soekarno (1957:28-29) voiced the "repurification", "rejuvenation", "regeneration", "reawakening", or "redynamication" for the nation building with dignified Indonesian character. He voiced the need for the mental revolution. Mental revolution is a new life movement which include reformation of ways of thinking, ways of working, and ways of life that hinder the advancement of our nation. Mental revolution also deals with the advancement and development of ways of thinking, ways of works, and good ways of life (Soekarno, 1957:35). One of the basic factor that can succeed such revolution is character education which has been being serious attentionto the government and institutions (Supriyono, 2012:162). This obviously is true partly because The National Law of education number 20, 2003 chapter II verse 3 states “... that national education functions as developing ability and forming valued nation character and civilization to smarten the nation lives to develop learners potential in order to be good Indonesian (Supriyono, 2012:163).

In fact, the Indonesian education has put character education on the important aspects of the curriculum. Of course, nation character building does not stop on the developing Indonesian learners' characters, but also must deal with the communities and all people from all sorts of life. So, in school character education is not enough. An innovation to developing good citizen character is then highly needed. Looking at this situation and using references of educational and training experience, the writer has come up with a new concept of character development the so-called $G^{*}$ GOLD Ways. G*GOLD Ways have been developed for training the development of characters for various people in different background, areas, and disciplines. It has been very obvious that good feedbacks show the positive influence in the participants life after training. Such positive feedbacks include positive thingking, positive feeling, highly motivated work, and good behavior. Looking at such feedback, the writer conducts a reflective study on the potential impact of $G^{*}$ GOLD Ways to contribute to people character development.

This study focuses on the reflection of how $G^{*}$ GOLD Approach has contributed to the people character development and this aims at describing the potential impact to contribute to people character development. G*GOLD Ways is defined as an approach to personal character in developing and taking action on the new ways of thinking, working, and good life using the concept of Greatness, Gratitude, Obedience, Love, and Discipline. This study is expected to be useful to education practitioners and all people expecting to develop new ways of thinking, working, and good life. This study is limited to the reflection of the 

a Reflective Study. Konstruktivisme, 8(1): 37-44.

development and implementation of $\mathrm{G}^{*} \mathrm{GOLD}$ Ways in forms of training for various people.

\section{G*GOLD Ways Development and Training Process}

Building a nation character also means building a citizen character. The ideas for the mental revolution (Soekarno, 1957) was very important. Looking at the 7 (seven) main efforts for implementing mental revolution which consist of (1) simple life, (2) clean and healthy life movement, (3) literacy movement, (4) the "gotong rojong" movement, (5) advancing national corporation, (6) spiritual development, and (7) national awareness (Soekarno, 1957:35), we can understand that a nation building as well as a nation character building is a complex concept and process. Therefore, the first main important things to consider is the definition of character itself.

Cunningham (2007:1) says that character is conceptualized in three ways, which are, (1) moral agent exemplification of the moral ideas of a society, (2) a set of personal qualities or traits, and (3) a complext system of habits. So, character building cannot just be done through character education at school, but also in the community where character education is meant as the development of individual potential in the normative character dealing with value and norms, the descriptive character dealing with morality, and personal character dealing with personal quality (Supriyono, 2012:165).

Character is the moral quality and direction of personal decition and behavior (Huitt, 2000:4). These are the cultivation of values and virtues (Nelson, Nelson, and Christoper, 2003:82). The individual moral quality can formualte the character of society (Supriyono, 2012:165), because character is a sociomoral competency (Bajovic, Rizzo, and Engemann, 2009:3). This relate "...with morality, social and civic aspects of lives, ethics, life skills, and personal responsibilities in lives" (Supriyono, 2012:167).

In terms of the national education, character education has been strategically included in the national curriculum for developing the so-called 20 traits. The fact is that today our prosocial and nation character still become important issues to be managed. Therefore, an innovative efforts in developing people character is highly demanded. Considering this situation, since 2010 the researcher developed a model of character development for all that has been called $G^{*}$ GOLD Ways.

The concept of $G^{*}$ GOLD which is Greatness, Gratitude, Obedience, Love, and Discipline was developed on the basis of (1) scientific reference of character education, (2) the writer experience in the world of both education and corporate values training, (3) prophetic and qur'anic studies, and (4) Pancasila values reference. There are three main basic concepts on this models including (1) Basic driving force called JACK (Jujur, Amanah, Cerdas, Bijaksana/Komunikatif), (2) the core concept which is $G^{*} G O L D$, and (3) the triangle of posittive conception. The three unified model can be drawn as the followings: 


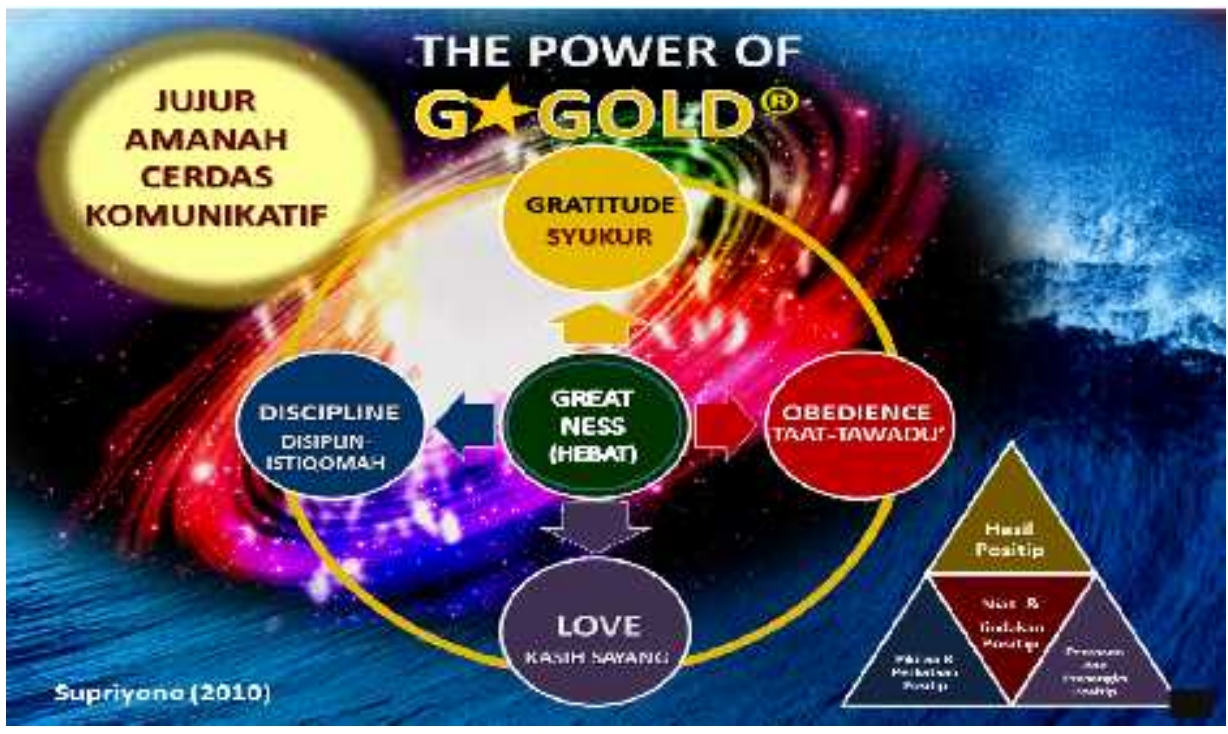

Figure 1: G*GOLD Ways Model (Supriyono, 2010)

This is the basic model that can be customized on the basis of profession and background of the subjects of character development, for example (1) for teachers, this model is blended into the so-called $G^{*} G O L D$ Ways on Becoming Great Teachers, (2) for students, this model is blended into the so-called $G^{*}$ GOLD Ways on Becoming Great Students, and (3) for parking officer, this model is blended into the so-called $G^{*} G O L D$ Ways on Becoming Great parking officer, etc. This basic concept is blended with the related studies in the related disciplines, for example for teachers this concept will be blended with instructional leadership using situational leadership model. This model was developed for the aim of training for all sorts of people or people from all sorts of disciplines and the development was processed using professional peer review.

Each bundle of training program is completed with instructional planning, module, presentation, and evaluation. The training is aimed at developing people good characters of being honest, smart, wise, communicative, and responsible as well as accountable with the greatness potentials, gratitude competence, obedience behavior, love conception, and discipline habituation. These are covered by positive perception, feeling, thinking, and action. The evaluation is designed using the concept of four levels of evaluation by Kick Patrick model consisting of Level 1 Evaluation-Reaction, Level 2 Evaluation-Learning, Level 3 EvaluationBehavior, and Level 4 Evaluation-Results (Kick Patrick, 1994).

The training method has been developed using the combination of PRIME, sugestopedia, and prophetic techniques. Instructional activities are equiped with music and real life experience. $G^{*} G O L D$ has been suggested to be employed in education (Supriyono, 2012) and can be combined with the practice of 5-E approach of instructional strategies (Supriyono, 2014). The 5-E means Envision, Empower, Emphatize, Enforce, and Enlighten. Each of the elements of $\mathrm{G}^{*} \mathrm{GOLD}$ can be drescrtibed as follows: 

a Reflective Study. Konstruktivisme, 8(1): 37-44.

Table 1: ${ }^{\star}$ GOLD Ways Model Conception (Supriyono, 2010)

\begin{tabular}{|c|c|c|c|c|}
\hline Greatness & Gratitude & Obedience & Love & Discipline \\
\hline $\begin{array}{l}\text { - Reading the } \\
\text { Lord creation, } \\
\text { self-potential, } \\
\text { other } \\
\text { potentials, } \\
\text { univers, and } \\
\text { environemnt } \\
\text { - Awareness of } \\
\text { self potential, } \\
\text { ethics and } \\
\text { values } \\
\text { - Awareness of } \\
\text { Intelectual } \\
\text { potential, } \\
\text { Socio } \\
\text { emotional } \\
\text { potential, } \\
\text { Spiritual } \\
\text { potential, and } \\
\text { physical } \\
\text { potential } \\
\text { - Awareness of } \\
\text { living } \\
\text { toghetherness }\end{array}$ & $\begin{array}{l}\text { - } \text { Being } \\
\text { positive to } \\
\text { self } \\
\text { - Being } \\
\text { positive to } \\
\text { the Lord } \\
\text { - Being } \\
\text { positive to } \\
\text { others } \\
\text { - Aceptance } \\
\text { and } \\
\text { improvement } \\
\text { - Learning to } \\
\text { live together } \\
\text { - Caring and } \\
\text { giving } \\
\text { - Maintaining } \\
\text { the balance } \\
\text { of life }\end{array}$ & $\begin{array}{l}\text { - Awareness and } \\
\text { development of } \\
\text { ethics and value } \\
\text { system } \\
\text { - Commitment and } \\
\text { obey to values, } \\
\text { norms, } \\
\text { regulation, and } \\
\text { any forms of } \\
\text { concencus } \\
\text { - Compliance to } \\
\text { values, norms, } \\
\text { regulation, and } \\
\text { any forms of } \\
\text { concencus }\end{array}$ & $\begin{array}{l}\text { - Gentle } \\
\text { communication } \\
\text { - Gentle care to } \\
\text { people and } \\
\text { environment } \\
\text { - Gentle } \\
\text { problem } \\
\text { solving } \\
\text { - Sharing and } \\
\text { Caring for } \\
\text { public values } \\
\text { and interest } \\
\text { - Trust and wise } \\
\text { interrelation } \\
\text { - Self and } \\
\text { community } \\
\text { help } \\
\text { - Envisioning, } \\
\text { Empowering, } \\
\text { Emphatizing, } \\
\text { Enforcing, and } \\
\text { Enlightenning }\end{array}$ & $\begin{array}{l}\text { - } \text { High } \\
\text { motivation } \\
\text { - Positive } \\
\text { motivation } \\
\text { - Being } \\
\text { punctual } \\
\text { - Trustworthy } \\
\text { and } \\
\text { complying } \\
\text { the } \\
\text { commitment } \\
\text { - Working for } \\
\text { results } \\
\text { - Establishing } \\
\text { Key Results } \\
\text { area and Key } \\
\text { Performance } \\
\text { Indicator } \\
\text { - Consistant in } \\
\text { achieving the } \\
\text { designed } \\
\text { objectives }\end{array}$ \\
\hline
\end{tabular}

\section{METHOD}

This study is a reflection of profesional training practices on the G*GOLD Ways character development conducted by the writer for various profession and people. The writer did not initially intend to conduct any researches such as action research, experimental research, or research and development; however, the writer as the developer and practitioner of the $G^{*} G O L D$ ways training always use such kinds of empirical notes and reflective practices. Reflective practice is "the persistent and careful consideration of any belief or supposed form of knowledge in the light of the ground that supports it and the figure condition to which it tends" (Sadeghi, 2013:71). Since this is a descriptive study of the professional practices, the writer uses the reflective study design. The design is aimed at looking at the practices and their evaluation results by using reflective practices records and notes and validated through peer audit. The data were taken from training practices since 2010 as the followings: 


\begin{tabular}{|c|c|c|c|}
\hline No & Training & Place/Year & Remarks \\
\hline 1 & $\begin{array}{l}\text { G*GOLD Ways for School Leaders } \\
\text { (Prinsipals and Vice Principals) }\end{array}$ & Kuala Kencana, 2010 & positive \\
\hline 2 & $\begin{array}{l}G^{*} \text { GOLD Ways of Effective Teachers } \\
\text { (Teachers from various schools) }\end{array}$ & Blitar, 2011 & positive \\
\hline 3 & $\begin{array}{l}G^{*} \text { GOLD Ways of Parenting } \\
\text { (Teachers from various schools and } \\
\text { parents from urbant areas) }\end{array}$ & Blitar, 2011 & positive \\
\hline 4 & $\begin{array}{l}\text { G*GOLD Ways of Becoming Great Sale } \\
\text { Person (Teh Sepak Bola Sale Persons) }\end{array}$ & Blitar, 2011 & positive \\
\hline 5 & 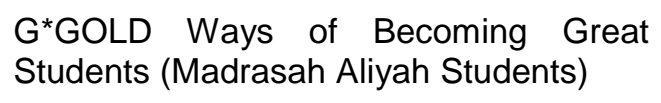 & Blitar, 2012 & positive \\
\hline 6 & $\begin{array}{l}\text { G*GOLD Ways of Becoming Great } \\
\text { Students (University Students) }\end{array}$ & $\begin{array}{l}\text { Blitar, 2011, 2012, } \\
2013\end{array}$ & positive \\
\hline 7 & $\begin{array}{l}\text { G*GOLD Ways of Parenting (Parents in } \\
\text { Villages) }\end{array}$ & Blitar, 2012 & positive \\
\hline 8 & $\begin{array}{l}\text { G*GOLD Ways of becoming } \\
\text { GreatTeachers (East Java Teachers) }\end{array}$ & Batu, 2012 & positive \\
\hline 9 & $\begin{array}{l}\text { G*GOLD Ways of Parenting (Madrasah } \\
\text { Ibtiaiyah Teachers) }\end{array}$ & Tulungagung, 2012 & positive \\
\hline 10 & $\begin{array}{l}\text { G*GOLD Ways of Becoming Great } \\
\text { Teachers (High School Teachers) }\end{array}$ & Samarinda, 2012 & positive \\
\hline 11 & $\begin{array}{l}\text { G*GOLD Ways of Becoming Great } \\
\text { School Leaders and Teachers (All level } \\
\text { School Leaders and Teachers) }\end{array}$ & Samarinda, 2012 & positive \\
\hline 12 & 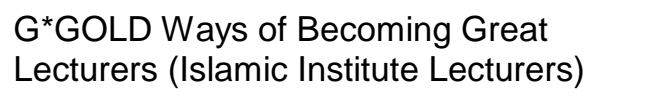 & Madura, 2013 & positive \\
\hline 13 & $\begin{array}{l}G^{*} \text { GOLD Ways of Becoming Great } \\
\text { Parking Officer (Dishub Blitar) }\end{array}$ & Blitar, 2014 & positive \\
\hline 14 & $\begin{array}{l}G^{*} \text { GOLD Ways of Becoming Great } \\
\text { Educator (All Levels School and Insitiute } \\
\text { Leaders and Teachers) }\end{array}$ & Blitar, 2015 & positive \\
\hline 15 & $\begin{array}{l}\text { G*GOLD Ways of Becoming Great } \\
\text { Teachers (SMP Teachers) }\end{array}$ & Blitar, 2015 & positive \\
\hline 16 & $\begin{array}{l}\text { G*GOLD Ways of Becoming Great } \\
\text { Students (SMP Students) }\end{array}$ & Blitar, 2015 & positive \\
\hline
\end{tabular}


The data were in forms of descriptive field notes and records of 4 Level evaluation. Level 1 which is reaction is evaluated by giving them rubric asking on all aspect of the training services. Level 2 which is learning is evaluated by giving them rubric of understanding on the concept of $G^{*}$ GOLD Ways with all its elements both before and after the training. Level 3 which is behavior is evaluated by checking whether the participants implement the concept of $G^{*}$ GOLD at their daily life and work and is checked after three months training. Level 4 which is result is evaluated by asking the leaders of organization or schools whether there is improvement in performance to their organization or schools. This is also checked after the three months training.

\section{RESULTS AND REFLECTION}

Reflecting the G*GOLD practices by analyzing the reflective field notes, evaluation, and feedbacks, it has been found out that in all training prtactices, all participants perceived that the training is very useful and improve not only their characters, but also ways of working. Looking at the results of level evaluation, the writer has found out that for all training practices in average the participants gave positive feedbacks. Mostly arround $1 \%$ to $2 \%$ of participants concerned on facilities and times. They also concerned on having more interactive as well as questions and answer session made by the trainer.

As for the results of Level 2 evaluation, in average the participants highly gain knowledge of good characters as offered using $G^{*}$ GOLD Ways and experience new enlightment for their life on the ways of thinking, working, and life. Mostly arround $1 \%$ to $2 \%$ of participants considered that the $G^{*} G O L D$ Ways was not important and made no effect on their ways of thinking, working, and life. Analyzing the record of level 3 evaluation, the writer found out that participants made use of the $\mathrm{G}^{*}$ GOLD Ways concepts and elements in their daily life both in their own living and their work living. Their leaders made feedback that almost all of the participants made good behavior improvement. Most of the leaders commented that arround $1 \%$ to $2 \%$ of the participants were difficult to change their good behavior.

This is concistant with the results of level 1 and 2 evaluations. The level 4 evaluation has shown that almost all partcipants made positive contribution to their organizations, schools, or institutes. In average arround $1 \%$ to $2 \%$ of the participants made no improvement in their contribution to their organizations, schools, or institutes. Having discussion with the designated leaders to interview using purposive sampling, the writer obtained feedback on the improvement for the training. These consist of (1) adding more times and making the focus of materials more narrowed, (2) adding more interactive communications, (3) openning more questions and answers.

The results showed that the $\mathrm{G}^{*} \mathrm{GOLD}$ Ways Approach to development of good characters in the form of training has contributed to the development of good characters in various professions and for people from various background. A change on the strategy and time allotment shall be done to improve the training results and potentially make $100 \%$ of the 
participants succeed by eliminating the $1 \%-2 \%$ of participants' problem. Reflecting the training experience and the record of training, there seemed a misslinking comception between the intention of the training and the intention of participants. This is mostly due to the different understanding on the method, such as the suggestopedia and the spiritual activities. Such things happen to lecturers. Therefore, sharing on this part can be highly recommended. The follow up with the outbound activities in 2 trainings turned out to be very useful and strong for enriching the participants awareness of the $G^{*} G O L D$ Ways concept.

\section{CONCLUSION AND RECOMMENDATION}

This study conclude that $G^{*}$ GOLD Ways Model of developing good character is compatible to various kinds of participants and disciplines. The model can be, then, used as the so-called the $G^{*} G O L D$ Approach to Character Education for all people.

It is recommended that this approach can be a reference to character education at schools as well as at the community for informal and non formal education. More valid scientfic researches such as the research and development and the experimental study on the use of the $G^{*} G O L D$ approach in character education are highly recommended.

\section{REFERENCES}

Bajovic, M., Rizzo, K, and Engemann, J. 2009. Character Education ReConceptualized for Practical Implementation. Canadian Journal of Educational Administration and Policy. Issue \#92, March 1, 2009.

Cunningham, C.A. 2007. Character Education in Public Schools: The Quest for Suitable Ontology. USA: National Louis University.

Huitt, W.G. 2000. Moral and Character Education. Presentation. Valdosta: Valdosta State University.

Kirkpatrick, D. L.1994. Evaluating training programs: the four levels.

San Francisco: Pergamon Press.

Berrett- KoehlerNelson, T., Nelson, M.D., Christoper, J.C. 2003. Culture and Character Education: Problem of Interpretation in Multicultural Society. Journal of Theoretical and Psychological Psy, 23(3): 1628).

Soekarno.1957. Satu Tahun Ketentuan (a Year of Decision). Jakarta: Kementrian Penerangan R.I.

Supriyono. 2010. ${ }^{\star}{ }^{*}$ GOLD Model of Leadership Development. Presentation. Kuala Kencana: YPJ.

Supriyono. 2012. Developing Character Education with Reference to Islamic Perspective. Widya Wacana. 14(2): 151-316.

Supriyono. 2014. Managing EFL Teachers' Instructional Behavior Change Using A Proposed 5-E Approach. Widya Wacana. 16(2): 87-103. 

a Reflective Study. Konstruktivisme, 8(1): 37-44. 